\title{
Operational and Efficient Production Functions: Measuring Efficiency in Abyek Cement Factory
}

\author{
Bijan Bidabad ${ }^{1} \quad$ Mahshid Sherafati ${ }^{2} \quad$ Roohollah Mohammadi $^{3}$
}

\begin{abstract}
In this paper, Leontief linear production functions with one product, and one activity are used to derive the production function of Abyek Cement Factory. The mathematical closed form of production function and also, profit, cost, and demand functions for production factors are obtained for the cited factory.

We tried to calculate Operational Production Function of Abyek Cement Factory. It was realized that Leontief linear production function is applicable, and its mathematical form can properly express the economic structure of production in a cement factory.

The efficient production function for this factory is also derived in this research. This function exhibits the costs incurred due to the inefficient production of the factory during different years. According to the findings, it was concluded that if the Abyek Cement Factory produces efficiently through employing optimal amounts of factors of production, it can reduce costs by 2I to 52 percent without any change in production level. Calculations were done for both short-term and long-term periods.
\end{abstract}

Keywords: Production function, Cost function, Cement, Efficiency, Inefficiency measurement

JEL: D22, LII, L6I

\section{Introduction}

Economically, the "Firm Theory" is grounded on the analytical fundamentals of microeconomics. ${ }^{4}$ A firm is defined as a technical unit that produces goods using production factors. The firm production function is the mathematical expression of the relationship between production factors and the product(s). Production factor can be any goods or services that are used in the process of production of new products; and can be the products of other firms. Production factors are classified within a specified period as constant and variable factors. Constant production factor is essential for production, but its amount remains unchanged according to the generated amount of the product. Constant production costs are imposed on firm and are not affected by short-term optimization decisions. In other words, whether the firm produces or not, the constant production factor in the specified period is not altered. This specified period that is expressed as a short time period here is the basis for defining the constant production factor. This means that if we consider this period as a very long period, then the constant production factor can be considered as a variable factor because the firm will be able to alter the application of this factor in the production process. Variable production factor is a factor that changes by changing the amount of production. For instance, in a cement factory, accumulated capital of the installments is considered as a constant production factor during a short period; however, gypsum, limestone, iron ore, and other similar production factors are defined as variable production factors that are in direct relationship with the production of clinker and cement.

The firm manager's decisions are in line with the facts that to what extent the production factors to be bought in order to maximize profits (and minimize costs of the firm) from selling the produced products.

I (B.A., M.Sc., Ph.D., Post-Doc.) Professor of Economics and economic advisor to.Fars \& Khuzestan Cement Company (FKCCo). Site: http://www.bidabad.com, Email:bijan@bidabad.com,

This paper is a summary of some parts of the research project: "Studying the economic structure of Abyek Cement Factory", Fars \& Khuzestan Cement Company (FKCCo), Bijan Bidabad. (Revised) Presented at International Conference on Business Strategy and Social Sciences (ICBSSS), Asian Economic and Social Society (AESS), Faculty of Technology Management and Business, Universiti Tun Hussein Onn Malaysia, and Pak Publishing Group. I6-I7 August 20I4, Kuala Lumpur, Malaysia.

${ }^{2}$ MBA Department. Management Faculty, Multimedia University, Malaysia. mahshidsherafati@gmail.com

${ }^{3} \mathrm{CEO}$ of Novin Pajoohane Research Institute, Tehran, Iran. rmohamadi58@gmail.com

${ }^{5}$ For more information, see microeconomics textbooks, particularly Henderson and Quandt (I982). 
Consider a production process in which the firm's manager employs two variable production factors of $\mathrm{x}$ a and $\mathrm{x} 2$ and one or more constant production factors to produce the $\mathrm{Q}$ product. The linear production activity is a process, in which a fixed proportion of one or more products are produced from a fixed proportion of one or more production factors. Linear homogeneous productions functions are of order one and thus, have constant economies of scale. In other words, if all factors increase (or decrease) at the same ratio, all products will increase (or decrease) similarly at that ratio. A linear production function is obtained from a set of linear production activities that are used simultaneously. As this production function will be used repeatedly in the next sections, it will be explained more in depth ${ }^{5}$.

\section{Theory and Literature}

\section{Linear Production Function with One Product and One Activity}

Consider a linear production activity in which a product is produced from $\mathrm{m}$ production factors. This activity is described completely by the set of coefficients $\mathrm{a}_{i} ; \mathrm{i}=\mathrm{I}, \ldots, \mathrm{m}$ that indicates the amount of the $\mathrm{i}^{\text {th }}$ production factor required to produce a unit of product. The required production factor for each production level is determined by the following relation:

$$
x_{i}=a_{i} q \quad i=1,2, \ldots, m
$$

The maximum level of production that can be achieved from a given set of production factors is equal to:

$$
q=\min \left(\frac{x_{i}}{a_{i}}\right), a_{i}>0
$$

Any production factor in this equation could be a limiting factor for the production level. According to equation (I), the value of $\mathrm{x}_{\mathrm{i}}$ is enough to produce the amount of $\mathrm{x}_{\mathrm{i}} / \mathrm{a}$. However, it is apparent that other production factors need to be sufficiently present in order to secure this level of production. Hence, the minimum value of $\mathrm{x}_{\mathrm{i}} / \mathrm{a}_{\mathrm{i}}$ recognizes the maximum level of production. Some parts of some production factors may not be used due to lack of other production factors. The isoquants curves of this production function are orthogonal, and their heads are located on the firm' production expansion path. Proportional increase of all factors means to go on the higher isoquant curve, and if a single production factor does not increase proportionally, the movement will occur on branches of the isoquant curve, and productions will no longer increase. As can be clearly perceived by the figure (I), in the isoquants curve, $\mathrm{q}^{0}=3$, the production level at point $\mathrm{A}$ is considered efficient, but at points $\mathrm{K}$ or $\mathrm{L}$ are not. It is because, at these two points, the same amount of product is produced but with higher production factors.

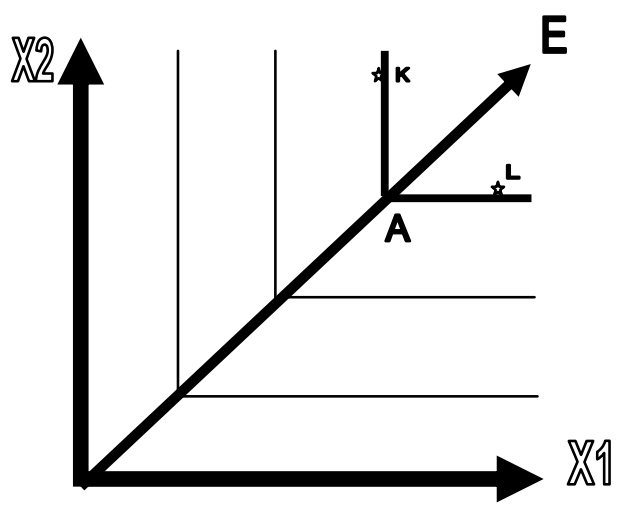

GRAPH I: Leontief Isoquants

Linear production with one product and multi-activities and linear production with multi-products and multi-activities are

${ }^{5}$ In economic textbooks, many production functions with various economic and mathematical specifications have been expressed. See Eatwell, Milgate, and Newman (1988) and Savabi-Asl, Bidabad, Shahrestani (1993). 
derivable as an extension of the above subject. ${ }^{6}$

\section{Production Function of Abyek Cement Factory}

In every firm, there is a special relationship amongst various production factors, including capital installments, labor, equipment, energy, fuel consumption and etc. with a specific definition. In other words, the way production factors are interrelated determines the production process, and it can consequently specify the mathematical form of the production function. The economic effects of all factors in a production function need to be specifically definable. In fact, these effects recognize the specifications of the production process. In order to define a production function for a specific firm, the existing specifications of the production process should be studied, and subsequently, they must be expressed in mathematical forms of specific production functions. These specifications are reviewed in the following.

\section{Economies of Scale}

Production functions can be homogenous. Homogeneity concept in production functions means that if all production factors are increased (or decreased) with a specified ratio; the production level will be increased (or decreased) at the same or lesser or more ratios. If the increase (decrease) in production level is exactly the same as in production factors increase (decrease), the production function is homogenous of degree one. If the ratio of increasing (decreasing) the production level is lower/greater than production factors increase (decrease), it is homogeneous of degree less/greater than one. In three modes of homogeneity in which the degree is one, lower and then one, economies of scale are constant, increasing, and decreasing, respectively. Mathematically, a production function is homogeneous of degree $\mathrm{k}$, if:

$$
f\left(t x_{1}, t x_{2}\right)=t^{k} f\left(x_{1}, x_{2}\right)
$$

For values of $\mathrm{k}>\mathrm{I}, \mathrm{k}=\mathrm{I}$ and $0<\mathrm{k}<\mathrm{I}$, economies of scale are increasing, constant, and decreasing, respectively. In homogeneous production functions, the firm's expansion is linear.

Based on the performed studies in the current research and Bidabad (I999) and Khayyambashi (I996) and Forsund and Hjalmarsson (1983), it can be inferred that in Abyek Cement Factory, economies of scale for all production factors are a constant return to scale. This is because of the relationship between cement production and production factors (including raw materials, electricity, fuel, etc.)

\section{Substitutability of Production Factors}

Substitutability of production factors refers to the ability to use a production factor instead of the other one; for instance, the substitution of fuel with electrical energy, or labor with capital equipment, and so on. In production functions, the technical rate of substitution indicates the amount of a production factor that can be replaced by another one at the same production level. Mathematically, this rate is shown by:

$$
R T S=-\frac{d x_{2}}{d x_{1}}=\frac{f_{1}}{f_{2}}
$$

Where " $\mathrm{d}$ " is for differentiation and $\mathrm{f}_{1}, \mathrm{f}_{2}$ are derivatives of the production function respect to $\mathrm{x}_{\mathrm{I}}$ and $\mathrm{x}_{2}$ factors of production. According to the performed studies on the structure of using production factors in Abyek Cement Factory, it was revealed that at least in the short term, no production factor could be substituted with another. The reason is related to the nature of the investments in cement plants, particularly those with high production capacity. For example, it is unfeasible for a factory that while maintaining the same production level, decreases one production factor (e.g., capital), and instead, employs another production factor (e.g., labor) as a substitute. Thus, the mathematical production function of Abyek Cement Factory should be designed in such a way to consider this matter that the substitutability of production factors is normally impossible in shortterm. The long-term design of production function allows to some extent, the substitution between capital and labor, as well as the substitution between different fuels (e.g., gas and fuel oil), or between fuels and electrical energy.

${ }^{6}$ See Bidabad, Bijan (1999) Studying the economic structure of Abyek Cement Factory, Fars \& Khuzestan Cement Co (FKCCo), http://www.bidabad/doc/karkhaneh-abyek.pdf 


\section{Technical Changes}

A parameter, which is generally defined in production functions, is gradual technical development and efficiency improvement of production factors productivities in the firm. On the other hand, the managerial decisions towards optimum utilization of various production factors are also concerned in this subject. Therefore, if the production function is defined for the long term, it is necessary to include such a variable for this phenomenon.

\section{Activities}

The current activities in a firm can be expressed based on single production lines. Each activity can produce one or more products by using several factors. If there are considerable differences among production lines, separate production functions for each of the activities can be defined and then added up. However, it should be noticed that this can intensify the mathematical complexity of the production function. Abyek Cement Factory has two separate production lines, which are similar in many attributes and also shared in some of the initial parts of the production process. In fact, the supply and raw material feeding facilities for both lines are shared. Therefore, it can be stated that if we study almost all the activities in a single framework, it can make the case easier to develop and understand with no damage to the subject.

\section{Production Domain}

The production domain, at least in the short term, is unchangeable due to special establishment conditions of capital equipment. In other words, the constructed production capacity cannot be easily increased, and hence, the production is feasible in a specific range, and even the maximum accessible capacity cannot be increased. Therefore, a production function should take this domain into account. In Abyek Cement Factory, the nominal production capacity is 2,250,000 tons of clinker per year, and according to this capacity, two production lines have been designed and constructed. This number must be used to limit the maximum mathematical production domain.

\section{Data Set and Method}

\section{Operational Production Function of Abyek Cement Factory}

Considering the presented specifications, it was realized that Leontief linear production function that its mathematical form is given by equation (2), can properly express the economic structure of production in this factory. Other researches that carried out to estimate the cement production function have also favored this function. Some examples can be stated, including the studies by Khayyambashi (1996) and, Forsund and Hjalmarsson (1983). The mathematical structure of this function consists of $\mathrm{m}$ technical coefficients (ai), and they need to be estimated to become operationally applicable.

By considering the development trend and method of employing production factors at Abyek Cement Factory during the years, and also by studying the structural improvements in this plant, it was perceived that using regressions for the entire concerned period may cause this problem that in estimations, the variances of the fitted values at the end of the period become high; because the calculated regressions using the least square method have optimal properties around the average values. On the other hand, technical developments have provided a situation in which the structure of applying production factors in last years be closer to the year after. Thus, considering this issue and the structure of Leontief production linear structure, for every production factor, technical coefficients were estimated in a special way. In some of them, the growth function was applied due to the more balanced trend of developments in using production factors. Moreover, for some other factors, the average of past years, depending on the year of structural developments was used. In these estimations, it was tried that the fitted values express the structure of last years of the period better, rather than the average trend.

Dividing production factors into constant and variable factors is of special complexities in the structure of Abyek Cement Factory. For instance, labor, which is typically considered as a variable production factor, does not comply in the concerned factory. This is because if the production level is low or high, it will not affect the number of employed labor, and consequently, the same level of wages should be paid. In fact, the employment contracts and legal limitations pragmatically restrict the dismissal of workers.

The mineral raw material is properly seen as a variable production factor, and it has a clear relationship with production level, and hence, production variations lead to the change of demand for this factor. Packing materials and a number of pockets 
depending on the combination of cement sales in pocket and bulk. Therefore, the number of required pockets cannot be specified regardless of supply or demand ratio of pocket and bulk sales.

Fuel and electricity consumption has a more sensible relationship with production level. In other words, these two production factors are amongst variable ones. However, the electricity consumption for non-production purposes (including heating in organizational buildings) can practically induce some troubles in the relationship between the consumed electricity and cement production level. Furthermore, due to technical problems in the production line, it can be sometimes observed that some parts of the production line are working operationally (such as furnaces), but nothing is produced. These issues, in some cases, have lowered the accuracy of the relationship between fuel or electricity consumption and the cement production level.

Although consumption of erosive and refractory materials as well as oil should be logically assumed as a variable production factor, the statistical records at Abyek Cement Factory show enormous fluctuations in consumption of zygment, ball, fire brick, refractory concrete, and oil, per tons of cement produced. Therefore, assuming this factor as a variable production factor may lead to some problems. Furthermore, consumption of other materials, due to the nature of this category of goods and services has many fluctuations. Hence, it can be claimed that consideration of it as a variable production factor is not flawless.

Even though according to the definition, capital depreciation is not considered as a production factor, it is accounted as a controversial figure in cost calculations. On the other side, if we consider capital depreciation as capital consumption, it can be regarded amongst the production factors. But it should be determined whether capital consumption relates to production level or not. Thus, it is a special issue. By considering the structure of the depreciation's estimation and accounting, they can be considered either separated from or related to the production level.

In long-term production functions, capital can be considered as a variable production factor, because the firm will be able to change its capital usage.

However, in the vast majority of the above-mentioned discussions, the perspective of the relationship between production factors and production level has been analyzed with regard to linear production functions. In these functions, the relationship between production factors and production level is a linear relation, and even in our pattern, it is a linear relationship with constant coefficients. The relationship between production factors and production level was assessed in an interrelated framework of constant technical coefficients. However, the non-linear and non-smooth nature of the mathematical relationship between these two variables is always apparent.

As mentioned before, for estimating a production function that better considers the past structure and past development trends to show future conditions, regression technique was not applied. Because, the major applicability of regressions is around the average, and when they are used for prediction because independent variables are often positioned away from the average, prediction variance becomes high. Thus, in order to resolve this problem, simpler mentioned methods were utilized for the prediction of values of technical coefficients for 1998-99. Its calculation method is present in the Analytical Information Bank of Abyek Cement Factory ${ }^{7}$. Overall, in order to find some predictions for the values of production factors and their prices, exponential growth method was used. In specific, for prediction of the ratios of production factors and production level, on the one hand, exponential growth method was used for the factors of labor, mineral raw material, and electricity, and then, the average of last years was applied for the rest of factors.

The production factors, which were taken as variable, and their technical coefficients are explained in the following. These figures are of the best efficiency (in terms of different statistical properties) in expressing the structure of Abyek Cement Factory in 1998-99. For expressing the mathematical structure of production in other years, some other suitable figures need to be applied.

Working hours per year per ton of cement produced: $\mathrm{al}=\mathrm{I} .97$

Tons of mineral raw materials per ton of cement produced: $\mathrm{a}_{2}=1.58$

Million KCal of fuel per ton of cement produced: $\mathrm{a}_{3}=0.77$

KW of electricity per ton of cement produced: $\mathrm{a}_{4}=\mathrm{I} 12.66$

Price of consuming materials (constant price 1997-98) per ton of cement produced: as $=4358.40$

${ }^{7}$ Bidabad, Bijan (1999) Studying the economic structure of Abyek Cement Factory, Fars \& Khuzestan Cement Co. (FKCCo), http://www.bidabad/doc/karkhaneh-abyek.pdf 
The mathematical form of the production function of Abyek Cement Factory is as follows:

$$
q=\operatorname{Min}\left(\frac{x_{1}}{1.97}, \frac{x_{2}}{1.58}, \frac{x_{3}}{0.77}, \frac{x_{4}}{122.66}, \frac{x_{5}}{4358.40}, \frac{2250000}{0.97}\right.
$$

q: tons of cement produced

The last term refers to the ratio of nominal factory capacity to the ratio of technical production for clinker production. Values of $\mathrm{x} 1, \ldots, \mathrm{X} 5$ show the usage of the factors one to five as follows:

xı: Labor work usage, hours per year

$\mathrm{x} 2$ : Mineral raw materials usage, tons

$\mathrm{x}_{3}$ : Fuel consumption, million $\mathrm{KCal}$

$\mathrm{x}_{\text {: }}$ Electricity usage, KW

Xs: Consuming materials at constant prices of 1997-98

\section{The cost function of Abyek Cement Factory}

Considering the theoretical characteristic of the duality of production and costs, it should be noted that production functions are interrelated with cost functions, and the discussion is much ample to be presented here. It is just required to state that if the production function is linear like equation (5), the cost function will be linear as follows:

$$
C=F+q \sum_{i=1}^{m} a_{i} p_{i}
$$

Where, $\mathrm{C}$ is the total cost, $\mathrm{F}$ is fixed cost, $\mathrm{a}_{i}$ is technical coefficient, $\mathrm{p}_{\mathrm{i}}$ is the price of production factor $\mathrm{i}$, and $\mathrm{q}$ is production level. In Abyek Cement Factory, fixed cost (F) can be presented as follows:

$$
F=C_{6}+C_{6}+C_{8}+C_{9}
$$

Where:

C6: Packing materials cost

$\mathrm{C}_{7}$ : Depreciation

C8: Other cost items

$\mathrm{C}_{9}$ : Gross investment

Packing materials cost can be considered as a variable factor, as it can be changed in case required based on the cement production in pocket or bulk. Therefore, packing materials cost is defined as below:

$$
C_{6}=e \cdot q^{*} \cdot a_{6} \cdot p_{6}
$$

Where " $\mathrm{e}$ " is a decision variable, equal to the ratio of cement pockets produced to the total cement production. The variables, a6 and $\mathrm{p}_{6}$ are the cost of each pocket, and the technical coefficient of packing materials (per pocket) (as a production factor) per ton of cement produced, respectively. In the Analytical Information Bank of Abyek Cement Factory, a6 has been estimated for 1998-99 as follows:

$$
a_{6}=7.56
$$

The value of $\mathrm{q}^{* *}$ can be gained from the relation $\mathrm{q}^{* *}=\mathrm{q}$. The production level is primarily determined according to equation (6) and afterwards, in order to calculate the cost, the production level of $q$ is replaced in equation (8) to find the packing cost considering the decision variable " $\mathrm{e}$ ", which is the ratio of cement produced in pocket to total cement production.

The depreciation cost is dependent on depreciation rate and capital at the end of each year, and on the other hand, the later variable needs to be calculated by using investment value. In addition, gross investment is an exogenous variable. On the whole, all these variables are contingent on the decision made by the manager of Abyek Cement Factory, but not on the cement production process. Other costs follow the same pattern, and therefore, the fixed cost function, F, can be presented as follows:

$$
F=7.56 e \cdot p_{6}+C_{7}+C_{8}+C_{9}
$$


The total cost function can be proposed as follows:

$$
C=7.56 e . q * p_{6}+c_{7}+c_{8}+c_{9}+q \cdot\left(1.97 p_{1}+1.58 p_{2}+0.77 p_{3}+1226 p_{4}++43584 p_{5}\right)
$$

Where:

pr: Price of one working hour (in Rials)

p2: Price of one ton of mineral raw materials (in Rials)

$\mathrm{P}_{3}$ : Price of one million KCal of fuel (in Rials)

$\mathrm{P}_{4}$ : Price of one KW of electricity (in Rials)

$\mathrm{P}_{5}$ : Price of consuming materials (the base year 1997-98) (in Rials)

$\mathrm{P}_{6}$ : Price of packing materials (in Rials)

Profit Function of Abyek Cement Factory

By using the achieved production and cost functions, the mathematical form of profit function can be perceived as follows:

$$
\pi=\left(e \cdot P_{P}+(1-e) \cdot P_{B}\right) \cdot q-C
$$

Where, $\mathrm{C}$ and $\mathrm{q}$ are obtained from equations (I0) and (5) respectively. $\pi$ is profit, $P_{P}$ and $P_{B}$ are selling prices of produced pocket and bulk type of cement, respectively. " $\mathrm{e}$ " is the decision variable as defined before. In profit maximization, the following point needs to be considered in partial derivatives:

$$
\frac{\partial \mathrm{C}}{\partial \mathrm{q}^{*}}=\frac{\partial \mathrm{q}}{\partial \mathrm{q}^{*}}=0
$$

This term would reflect that based on equations (5) and (I0), in the cement production process, while the cement is produced only in bulk, the cement production costs are not related to cement produced in the pocket, and therefore, variations of production costs to cement production level in the pocket is zero. Moreover, production level variations to cement production in the pocket will be also zero. As mentioned before, as cement production in the pocket is not a restrictive factor; thus, it can be placed out of the production's optimization process. However, after cement production in bulk, it can be placed in the profit optimization process. As soon as the firm's manager decides to pack some volumes of cement into pockets, packing costs according to this volume of pocket cement will be added to the costs. This issue is clearly demonstrated by inserting equation (8) into the cost function. On the other hand, considering the varied price of the pocket cement, the increase in the firm's income from selling the pocket cement has also been included in function (II). Application of the two variables of $\mathrm{q}$ and $\mathrm{q}^{\text {ix }}$, which are equal, and the latter one is an auxiliary variable, is for this reason that was explained beneath equation (8).

\section{Demand Functions for Production Factors of Abyek Cement Factory}

Considering the mathematical form of Leontief function, the demand functions of factors do not depend on their prices and are calculated only from optimum production. In other words, the required value of each production factor can be gained from the following formula:

$$
x_{i}=a_{i} q
$$

Where values of xi are the demands for production factors, $\mathrm{q}$ is the production level, and $a_{i}$ stands for technical coefficients of production.

$$
\begin{aligned}
& x_{1}=1.97 q \\
& x_{2}=1.58 q \\
& x_{3}=0.77 q \\
& x_{4}=122.66 q \\
& x_{5}=4358.40 q
\end{aligned}
$$

Demand functions of production factors present the firm's need towards each of various production factors relating to the production level. Efficient Production Function of Abyek Cement Factory

According to the previously mentioned discussions, if we consider the minimum values of technical coefficients of production $\left(a_{i}\right)$ during the period, and construct the Leontief linear production function accordingly, a production function will be extracted that is of the most efficient conditions of cement production in all the past years of performance of Abyek Cement 
Factory. i.e., $a_{i}$ can be obtained as follows:

$$
a_{i}^{*}=\operatorname{Min}\left\{a_{i t}, t=1361-62, \ldots, 1376-1377\right\} \quad i=1,2,3,4,5
$$

where,

$$
a_{i t}=\frac{x_{i t}}{q_{t}}
$$

The values of $\mathrm{q}_{\mathrm{t}}$ and $\mathrm{xit}$ are the cement production in year $\mathrm{t}$ and the usage of the $\mathrm{i}^{\text {th }}$ production factor in year $\mathrm{t}$, respectively. In this case, the efficient production function will be gained that its figures are presented in the Analytical Information Bank at Abyek Cement Factory. The mathematical form of this function is as follows:

$$
q=\min \left(\frac{x_{1}}{2.06}, \frac{x_{2}}{1.53}, \frac{x_{3}}{0.50}, \frac{x_{4}}{91.00}, \frac{x_{5}}{1598.66}, \frac{2250000}{0.97}\right)
$$

The optimal need to each production factor is obtained by using the technical coefficients of equation (I4) for each year:

$$
x_{i t}^{*}=a_{i}^{*} \cdot q_{i}^{*}
$$

The excess usages more than the optimal values needed for each production factor can be gained from the below equation:

$$
E_{i t}=x_{i t}^{*}-x_{i t}
$$

The inefficiency cost in the usage of production factors can be gained from the following equation:

$$
H_{1 t}=\sum_{i=1}^{5} E_{i t} \cdot p_{i t}
$$

The lost opportunity cost of the cement not produced due to inefficient production can be gained from the following equation:

$$
H_{2 t}=\left(q_{t}-q_{t}^{*}\right) \cdot p_{t}
$$

The lost profit due to not using the remained production capacity can be obtained from the following relation:

$$
H_{3 t}=-\left(\frac{2250000}{k_{t}}-q_{t}^{*}\right) \cdot\left(p-\left(c_{t}-L_{t}\right) / q_{t}\right)
$$

Where Lt and kt are the actual overhead costs and the ratio of clinker to cement, respectively, and $C_{t}$ here is short term cost. Total inefficiency cost at Abyek Cement Factory in financial year t can be obtained from the following relation:

$$
H_{t}=H_{1 t}+H_{2 t}+H_{3 t}
$$

\section{Findings}

The calculation details of all of these numbers are fully presented in the Analytical Information Bank of Abyek Cement Factory for studying the economic structure of the factory. Due to the significance of the issue, a summary of some tables out of several hundred related tables is provided as follows. Table-I shows the ratio of each production factor to the production volume in the same year: 
TABLE I: Ratios of Factors of Production to Production Level

\begin{tabular}{|c|c|c|c|c|}
\hline & \multicolumn{4}{|c|}{ Financial year } \\
\hline & I994-95 & I995-96 & I996-97 & I997-98 \\
\hline Labor, hours per ton of cement produced & 2.14 & 2.23 & 2.35 & 2.06 \\
\hline Tons of mineral raw materials per ton of cement produced & 1.62 & 1.65 & 1.55 & 1.59 \\
\hline $\begin{array}{l}\text { Packing materials (number of pockets) per ton of cement } \\
\text { produced }\end{array}$ & 5.04 & 7.85 & 6.09 & 8.73 \\
\hline Million KCal of fuel per ton of cement produced & 0.80 & 0.83 & $0.7 \mathrm{I}$ & 0.76 \\
\hline KW of electricity per ton of cement produced & 108.0 & I I8.0 & II 2.0 & II 2.0 \\
\hline $\begin{array}{l}\text { Depreciation per ton of cement produced (base year I997- } \\
\text { 98) (Rials) }\end{array}$ & 826.4 & 741.2 & I I 56.2 & I7I0.9 \\
\hline $\begin{array}{l}\text { Consuming materials (erosive, refractory, oil) per ton of } \\
\text { cement produced }\end{array}$ & 3530.0 & 4459.4 & 4421.9 & 4193.8 \\
\hline $\begin{array}{l}\text { Other materials per ton of cement produced (the base year } \\
\text { I997-98) }\end{array}$ & 4703.2 & 6238.5 & 5691.2 & 7136.9 \\
\hline $\begin{array}{l}\text { Gross investment in Rials per ton of cement produced (the } \\
\text { base year 1997-98) }\end{array}$ & 2940.6 & 2608.8 & I 3079.5 & 2329.5 \\
\hline
\end{tabular}

Table-2 calculates some statistics from the above table (built for a long-term period).

In table-3, the efficient production function for different years has been calculated. According to this, efficient production based on the minimum ratios of usage of factors has been calculated, and the percentage of production's inefficiency is presented.

TABLE 2: Statistics of Ratios of Production Factor to Production (1983-98)

\begin{tabular}{|c|c|c|c|c|c|}
\hline & Min & Max & Ave & Medium & $\begin{array}{l}\text { Standard } \\
\text { Deviation }\end{array}$ \\
\hline Labor, hours per year & 2.06 & 5.53 & 3.30 & 3.03 & 1.09 \\
\hline Mineral raw materials, tons & I.53 & 1.93 & 1.62 & 1.60 & 0.09 \\
\hline Packing materials (no. pockets) & 1.35 & 17.49 & 8.49 & 7.48 & 5.19 \\
\hline Fuel, Million KCal & 0.50 & 1.05 & 0.78 & 0.79 & 0.13 \\
\hline Electricity, KW & 91.00 & I4I.00 & I I8.68 & II 6.50 & 12.36 \\
\hline $\begin{array}{l}\text { Depreciation (capital consumption), Rials } \\
\text { (base year I997-98) }\end{array}$ & $74 \mathrm{I} .2$ & I9506.0 & 5416.7 & I633.2 & 6104.3 \\
\hline Consuming materials (erosive, refractory, oil) & I598.6 & 4459.4 & 3059.4 & 2849.6 & I057.6 \\
\hline $\begin{array}{l}\text { Other materials, Rials (constant prices, base } \\
\text { year I997-98) }\end{array}$ & -203.8 & 7136.9 & 3296.9 & 3133.2 & 2219.4 \\
\hline $\begin{array}{l}\text { Gross investment, Rials (constant prices, base } \\
\text { year } 1997-98 \text { ) }\end{array}$ & -197.8 & 13079.5 & $4 \mathrm{I} 23.5$ & 3338.2 & 3467.8 \\
\hline
\end{tabular}


TABLE 3: Short-term Efficient Production Function with Minimum Ratios of Production Factors to Production Level Financial year

\begin{tabular}{lcccc}
\cline { 2 - 4 } & I994-95 & I995-96 & I996-97 & I997-98 \\
\hline $\begin{array}{l}\text { Efficient production according to the short-term } \\
\text { minimum ratio of production factors to } \\
\text { production level }\end{array}$ & $2,319,58$ & $2,277,412$ & $1,959,949$ & $2,112,673$ \\
\hline $\begin{array}{l}\text { Difference between operational and efficient } \\
\text { productions }\end{array}$ & $-27,499$ & $-160,857$ & $-24,912$ & 0 \\
\hline Percentage of production's inefficiency & $-1.2 \%$ & $-7.1 \%$ & $-1.3 \%$ & $0.0 \%$
\end{tabular}

In table-4, according to optimal production, the required values of production factors are calculated.

TABLE 4: Short-term Optimal Need to Production Factors

Financial year

\begin{tabular}{|c|c|c|c|c|}
\hline & I994-95 & $1995-96$ & I996-97 & I997-98 \\
\hline The optimal need to labor, hours per year & $4,779,068$ & $4,692,173$ & $4,038,102$ & $4,352,760$ \\
\hline The optimal need to mineral raw materials, tons & $3,551,690$ & 3,487, I I I & $3,001,021$ & $3,234,867$ \\
\hline The optimal need to fuel, million Kcal & $\mathrm{I}, \mathrm{I} 6 \mathrm{I}, 3 \mathrm{I} 2$ & $\mathrm{I}, \mathrm{I} 40, \mathrm{I} 97$ & 981,258 & $1,057,719$ \\
\hline The optimal need to electricity, KW & $2 \mathrm{II}, 082,47$ & $207,244,47$ & $178,355,38$ & $192,253,24$ \\
\hline $\begin{array}{l}\text { The optimal need to consuming materials (erosive, } \\
\text { refractory, oil) (Million Rials) }\end{array}$ & 3,708 & 3,640 & 3,133 & 3,377 \\
\hline
\end{tabular}

Afterward, the excess usages of production factors more than the optimal needed values are exposed by table-5. The numbers in table-5 are presented in table- 6 as the percentage of production factors, which is required for the optimal case. Consequently, the costs of excess usages of production factors are obtained by multiplying their values to their prices as shown by table- 7 .

In table 8, inefficiency costs values, and as proportions of profit, cost, or capital are demonstrated. This table reflects that if Abyek Cement Factory produces efficiently, it can reduce costs in the concerned period by 20 to 50 percent, without any change in the production level.

TABLE 5: Difference of Optimal Need and Operational Consumption of Factors in Short-term

Financial Year

\begin{tabular}{|c|c|c|c|c|}
\hline & I994-95 & 1995-96 & I996-97 & $1997-98$ \\
\hline $\begin{array}{l}\text { Excess usage of working hours per year more than } \\
\text { optimal need }\end{array}$ & $-136,132$ & $-35,635$ & $-509,994$ & 0 \\
\hline $\begin{array}{l}\text { Excess usage of mineral raw materials more than } \\
\text { optimal need }\end{array}$ & $-169,455$ & 0 & 0 & -I I 6,062 \\
\hline $\begin{array}{l}\text { Excess usage of million KCal of fuel more than optimal } \\
\text { need }\end{array}$ & $-664,929$ & $-6 I 8,59 I$ & $-401,502$ & $-553,854$ \\
\hline $\begin{array}{l}\text { Excess usage of KW of electricity more than optimal } \\
\text { need (Million Rials) }\end{array}$ & -36.4 & -42.5 & -38.4 & -44.4 \\
\hline $\begin{array}{l}\text { Excess usage of consuming materials (erosive, } \\
\text { refractory, oil) more than optimal need (Million Rials) }\end{array}$ & $-4,382$ & $-5,797$ & $-5,423$ & $-5,482$ \\
\hline
\end{tabular}


TABLE 6: The Percentage of Inefficient Usage of Production Factors

Financial year

\begin{tabular}{|c|c|c|c|c|}
\hline & I994-95 & $1995-96$ & I996-97 & I997-98 \\
\hline Percentage of inefficient usage of labor & $-2.8 \%$ & $-0.8 \%$ & - II.2\% & $0.0 \%$ \\
\hline Percentage of inefficient usage of mineral raw materials & $-4.6 \%$ & $0.0 \%$ & $0.0 \%$ & $-3.5 \%$ \\
\hline Percentage of inefficient usage of fuel & $-36.4 \%$ & $-35.2 \%$ & $-29.0 \%$ & $-34.4 \%$ \\
\hline Percentage of inefficient usage of electricity & $-\mathrm{I} 4.7 \%$ & $-17.0 \%$ & $-17.7 \%$ & $-\mathrm{I} 8.8 \%$ \\
\hline $\begin{array}{l}\text { Percentage of inefficient usage of consuming materials (erosive, } \\
\text { refractory, oil) }\end{array}$ & $-54.2 \%$ & $-61.4 \%$ & $-63.4 \%$ & $-61.9 \%$ \\
\hline
\end{tabular}

TABLE 7: Cost of Excess Usage of Production Factors in Short Term (Million Rials)

Financial year

\begin{tabular}{|c|c|c|c|c|}
\hline & \\
\hline & $\begin{array}{c}1994- \\
95\end{array}$ & $\begin{array}{l}\text { 1995- } \\
96\end{array}$ & $\begin{array}{l}\text { I996- } \\
97\end{array}$ & $\begin{array}{l}\text { I997- } \\
98\end{array}$ \\
\hline Cost of excess usage than optimal need for labor & $-42 I$ & $-\mathrm{I} 36$ & $-2,302$ & 0 \\
\hline Cost of excess usage more than the optimal need for mineral raw materials & -208 & 0 & 0 & $-3 I 3$ \\
\hline Cost of excess usage more than optimal need for fuel & $-1,436$ & $-2,407$ & $-2,007$ & $-3,419$ \\
\hline Cost of excess usage more than optimal need for electricity & $-1,598$ & $-2,374$ & $-2,666$ & $-3,904$ \\
\hline Cost of excess usage more than optimal need for consuming materials & $-2,588$ & $-4,570$ & $-4,883$ & $-5,482$ \\
\hline Total costs of inefficient usage of production factors in short term & $\underline{-6,253}$ & $\underline{-9,489}$ & $\underline{-11,859}$ & $-13,120$ \\
\hline$\%$ of the cost of excess usage to the optimal need for labor & $7 \%$ & $\mathrm{I} \%$ & $19 \%$ & $0 \%$ \\
\hline $\begin{array}{l}\text { Percentage of the cost of excess usage to the optimal need for mineral raw } \\
\text { materials }\end{array}$ & $3 \%$ & $0 \%$ & $0 \%$ & $2 \%$ \\
\hline$\%$ of the cost of excess usage to the optimal need for fuel & $23 \%$ & $25 \%$ & $17 \%$ & $26 \%$ \\
\hline$\%$ of the cost of excess usage to the optimal need for electricity & $26 \%$ & $25 \%$ & $22 \%$ & $30 \%$ \\
\hline$\%$ of the cost of excess usage to the optimal need for consuming materials & $4 \mathrm{I} \%$ & $48 \%$ & $41 \%$ & $42 \%$ \\
\hline Total & $\underline{100 \%}$ & $\underline{100 \%}$ & $\underline{100 \%}$ & $\underline{100 \%}$ \\
\hline
\end{tabular}

TABLE 8: Costs of Inefficient Production in Short Term (Million Rials)

\section{Financial year}

\begin{tabular}{|c|c|c|c|c|}
\hline & I994-5 & I995-6 & I996-7 & I997-8 \\
\hline $\begin{array}{l}\text { Opportunity cost of the cement not produced due to } \\
\text { inefficient production }\end{array}$ & -942 & $-7,468$ & $-\mathrm{I}, 50 \mathrm{I}$ & 0 \\
\hline Costs of inefficient usage of production factors in short term & $-6,253$ & $-9,489$ & $-\mathrm{II}, 859$ & $-13,120$ \\
\hline Lost profit due to not using the remained production capacity & $-3,097$ & $-6,470$ & $-27,40 \mathrm{I}$ & $-21,409$ \\
\hline
\end{tabular}




\begin{tabular}{|c|c|c|c|c|}
\hline Total cost of inefficient production in short term & $-\underline{-10,292}$ & $-23,428$ & $\underline{-40,761}$ & $\underline{-34,529}$ \\
\hline Ratio of cost of inefficient production to profit in short term & $-30.4 \%$ & $-69.5 \%$ & $-\mathrm{I} 04.7 \%$ & $-61.2 \%$ \\
\hline $\begin{array}{l}\text { Ratio of cost of inefficient production to the costs in short } \\
\text { term }\end{array}$ & $-21.3 \%$ & $-33.4 \%$ & $-52.1 \%$ & $-32.5 \%$ \\
\hline $\begin{array}{l}\text { Ratio of cost of inefficient production to gross investment in } \\
\text { short term }\end{array}$ & $-1.5 \%$ & $-2.5 \%$ & $-3.4 \%$ & $-2.5 \%$ \\
\hline $\begin{array}{l}\text { Ratio of cost of inefficient production to net investment in } \\
\text { short term }\end{array}$ & $-1.8 \%$ & $-3.0 \%$ & $-4.2 \%$ & $-3.2 \%$ \\
\hline
\end{tabular}

\section{Conclusion}

This paper is in the field of empirical microeconomics; specifically cement manufacturing industry, and the focus of the study is based in such kind manufactory. It treats the relationship between production factors and production level based on production functions.

In every firm, there is a special relationship amongst various production factors, including capital installments, labor, equipment, energy, fuel consumption and etc. with specific definitions. In other words, the way production factors are interrelated determines the production process, and it can consequently specifies the mathematical form of the production function. In order to define a production function for a specific firm, the existing specifications of the production process should be studied, and subsequently, they must be expressed in mathematical forms of specific production functions. These specifications are reviewed in this paper, such as economies of scale, substitutability of production factors, technical changes, activities, and production domain. In this regards, within cement manufacturing, these subjects were analyzed theoretically and investigated empirically. A linear production function is obtained from a set of linear production activities that are used simultaneously as theoretical debates conclude.

In addition, the paper treats the cost, profit, and production factors' demand functions. The efficient production function for this factory is introduced. This function exhibits the extra cost incurred due to inefficient production of the factory during different years. According to the calculated findings, it was concluded that if the Abyek Cement Factory produces efficiently by employing optimal amounts of factors of production, it can highly reduce its costs without any decrease in production level.

In the next step, we tried to calculate Operational Production Function of Abyek Cement Factory. It was realized that Leontief linear production function is applicable that its mathematical form can properly express the economic structure of production in a cement factory. Considering the structure of Leontief production linear structure, for every production factor, technical coefficients were estimated. Calculations were done for both short-term and long-term periods. According to this, efficient production based on the minimum ratios of usage of factors has been calculated, and the required values of production factors were obtained as well. Afterward, the excess usages of production factors more than the optimal needed values are measured. Consequently, the costs of excess usages of production factors are obtained.

The ratio of the costs due to inefficient production to profit in short-term is measured as to be from $-30 \%$ to $-104 \%$ in different years. The ratio of the costs due to inefficient production to the costs in short-term was estimated as $-21 \%$ to $-52 \%$. This means that the factory can highly optimize its production activity if the optimal combination of production factors is applied.

Application of the mathematical methods in the calculation of analyzed functions results to give useful analytical tools not only for the Abyek Cement Co. in question but for all cement companies as well.

\section{References}

Azizian, M. (1984). Cement, Ketabsara Publications, Tehran, Iran.

Bidabad, Bijan (1999). Studying the Economic Structure of Abyek Cement Factory. Fars \& Khuzestan Cement Co (FKCCo), Tehran, Iran. http://www.bidabad/doc/karkhaneh-abyek.pdf.

Bidabad, Bijan; Mahshid Sherafati, Roohollah Mohammadi. (2014) A Financial Model for Economic Analysis of Cement Factory. International Conference on Business Strategy and Social Sciences (ICBSSS), Asian Economic and Social Society (AESS), Faculty of Technology Management and Business, Universiti Tun Hussein Onn Malaysia, and Pak Publishing Group. 16-I7 August 2014, Kuala Lumpur, Malaysia. 
http://www.bidabad.com/doc/abyekanalysis-short-en.pdf

Bidabad, Bijan, Nahid Kalbasi Anaraki. Effects of Iran's WTO accession on the cement industry. Effects of Iran's WTO accession on the cement industry. With co-operation of Nahid Kalbasi Anaraki. European Cement Conference 2004 proceedings, 4th conference and exhibition for the trends, the environment, emissions trading, markets, production and processing technology of cement in Europe, I5-I6 March 2004, Barcelona, Spain, pp.3.I-3.8, Pro Publications International Ltd. http://www.bidabad.com/doc/cement-wto-barcelona.pdf

Borhani, A., \& Saghaeian-nejad, H., \& Taeb, A. (1996). Estimation of the cost function for cement industry. Proceeding of the second international conference on Cement Industry, Energy, and Environment (CIEE), 333-342. Tehran, Iran.

Clark, K.B. (1980, Dec.). Unionization and productivity: micro-econometric evidence. The Quarterly Journal of Economics, 613-639. http://dx.doi.org/I0.3386/w0330.

Diaz-Alejandro, C.F. (I974). Labour Productivity and Other Characteristics of the Cement Plants: an International Comparison. Discussion Paper No. I05. Economic Growth Center, New Haven, Connecticut. http://www.econ.yale.edu/growth_pdf/cdpI05.pdf

Diewert, W.E. (I97I, Jan.). An application of the Shephard duality theorem: a generalized Leontief production function. Journal of Political Economy, 79, 48I-507. http://dx.doi.org/I0.1086/259764.

Eatwell, J., \& Milgate, M. \& Newman, P. (1988). The new Palgrave dictionary of economics. MacMillan.

Forsund, F.R. \& Hjalmarsson, L. (1983, Sep.). Technical progress and structural change in the Swedish cement industry 1955 I979, Econometrica, vol. 51, no.5. http://dx.doi.org/I0.2307/I912284.

Henderson, J.M., \& Quandt R.E. (I980). Microeconomic Theory, a Mathematical Approach. Third Edition, Mc-Graw-Hill. Johansen, L. (1972). Production Functions, Amsterdam, North-Holland Publishing Co.

Khayyambashi, B. (1996). The production function and its econometrics with regard to the cement industry in Iran. Proceeding of the second international conference on cement industry, energy, and environment (CIEE), 343-352. Tehran, Iran.

Savabi-asl, F., Bidabad, B., \& Shahrestani, H. (1993). Estimation of Iran Macro-Investment Function by Considering Different Production Functions. Master of Science dissertation in economics, Islamic Azad University, Tehran, Iran.

Taeb, A. \& Ali-Ahmadi, A. (1996). The Final Price of Cement Production, Proceeding of the second international conference on cement industry, energy, and environment (CIEE), 323-332, Tehran, Iran.

Thuesen, G.J., \& Fabrycky, W.J. (I993). Engineering Economy, Prentice-hall $8^{\text {th }}$ edition.

\section{Copyrights}

Copyright for this article is retained by the author(s), with first publication rights granted to the journal. This is an open-access article distributed under the terms and conditions of the Creative Commons Attribution license (http://creativecommons.org/licenses/by/4.0/) 